\title{
Reducing Child Malnutrition in Tanzania Combined Effects of Income Growth and Program Interventions
}

\author{
Harold Alderman \\ The World Bank \\ halderman@worldbank.org \\ Hans Hoogeveen \\ The World Bank \\ jhoogeveen@worldbank.org \\ Mariacristina Rossi \\ The World Bank and University of Rome "Tor Vergata", Italy \\ rossi@economia.uniroma2.it
}

\begin{abstract}
World Bank Policy Research Working Paper 3567, April 2005
The Policy Research Working Paper Series disseminates the findings of work in progress to encourage the exchange of ideas about development issues. An objective of the series is to get the findings out quickly, even if the presentations are less than fully polished. The papers carry the names of the authors and should be cited accordingly. The findings, interpretations, and conclusions expressed in this paper are entirely those of the authors. They do not necessarily represent the view of the World Bank, its Executive Directors, or the countries they represent. Policy Research Working Papers are available online at http:/ / econ.worldbank.org.
\end{abstract}

The authors thank (in alphabetical order): Awudu Abdulai, Kathleen Beegle, Deon Filmer, Philippe Krynen, Valerie Leach, Mildred McLachlan, Meera Shekar and participants to seminars at the World Bank and in Dar es Salaam for useful comments, suggestions and other types of assistance. Financial support by the Italian Trust Fund for Children and Youth is gratefully acknowledged. 


\begin{abstract}
Malnutrition is associated with an inadequate diet, poor health and sanitation services and insufficient care for young children. A combination of income growth and nutrition interventions are therefore suggested to adequately tackle this issue (Haddad et al. 2003), yet evidence to support this claim is often not available, especially for African settings. This paper evaluates the joint contribution of income growth and nutrition interventions towards the reduction of malnutrition. Using a four round panel data set from northwestern Tanzania we estimate the determinants of a child's nutritional status, including household income and the presence of nutrition interventions in the community. The results show that better nutrition is associated with higher income, and that nutrition interventions have a substantial beneficial effect. Policy simulations make clear that if one intends to halve malnutrition rates by 2015 (the MDG objective), income growth will have to be complemented by large scale program interventions.
\end{abstract}

Keywords: nutrition, program evaluation, income growth, Tanzania, MDG 


\section{Introduction}

The Millennium Development Goals (MDGs) consider income poverty and malnutrition indicators of poverty that should, relative to their 1990 levels, be halved by 2015. This raises the question whether nutrition and income poverty measure different dimensions of the same development strategy. In particular, would a growth strategy that might achieve a significant increase in GDP as well as a reduction in income poverty, also be sufficient to attain the nutrition MDGs? Or does malnutrition respond differently to income growth than does income poverty?

Increases in income are clearly important for reducing malnutrition. Greater incomes at the household level allow families to spend more on food, clean water, hygiene and preventive and curative health care. It allows them to have a more diversified diet and to obtain more effective childcare arrangements. At the community level, greater income will eventually lead to better access to and higher quality health care, improved water and sanitation systems and greater access to information.

Empirical evidence supports the importance of income growth for the reduction of

malnutrition. A recent study using household survey data from 12 countries (including three African countries: Kenya, Mozambique, and South Africa) estimates the magnitude of the response of weight-for-age to income growth (Haddad et al. 2003). Under a scenario of sustained per capita income growth of $2.5 \%$ per annum, the average reduction in the fraction of underweight children would be between $27 \%$ and $34 \%$. This average hides substantial inter country variation, even within Africa. The reduction could be as high as $42 \%$ (Kenya) or as low as 14\% (South Africa).

Thus, Haddad et al. (2003) suggest that complementary instruments would be needed. However, while there is a body of clinical and programmatic evidence on which interventions are most promising (Allen and Gillespie, 2001), there is comparatively little data that indicates how nutrition interventions could augment income growth, especially in Africa, the one region in which malnutrition rates have not yet begun to decline (de Onis et al. 2004). Papers that do assess the impact of interventions on nutritional status, often deal with programs such as food aid and food for work in the aftermath of a drought shock (Yamano et al. forthcoming; Quisumbing 2003). Others such as Christiaensen and 
Alderman (2004) deal with the additional impact of nutrition education over the more general impact of schooling.

This paper focuses on the role of income growth in combination with two types of nutrition interventions in northwestern Tanzania, community driven supplementary feeding of young children, feeding posts, and child feeding carried out in crèches run by an international NGO, Partage. The implementation of these programs was likely to be an emergency response yet these crises were not directly issues of food scarcity. In any case, the study does not assess the impact of the provision of food per se, but of the package of services, comprising of the provision of food, awareness creation, day and medical care, that accompany the intervention.

The current study looks at anthropometric measures of child nutritional status. We study the degree to which increases in resources at household level and participation in nutrition programs contribute to the reduction of child malnutrition. Other determinants of nutritional status, such as access to health care, parental human capital and environmental factors are also considered. Our study examines the impact of the availability of program interventions on the nutritional status of children rather than the impact of participation itself. While both approaches convey useful information, Heckman, Lalonde, and Smith (1999) observe in their review of econometric methodologies for evaluation that often it is the former that is of policy relevance.

The remainder of the paper is as follows. Section 2 describes the data set used. Section 3 illustrates the children's health status in the Kagera region of Tanzania. Section 4 presents the econometric specification used and the estimated results according to different specifications. Section 5 continues with policy implications that the analysis implies. Section 6 concludes the paper.

\section{The Data Set}

The data used for this study come from a longitudinal living standards survey of households conducted in Kagera, a region of Tanzania with comparatively high adult mortality in the first decade of the AIDS epidemic. The region is located to the west of Lake Victoria and borders the Rakai district of Uganda to the north, and Burundi and Rwanda to the west. 
The dataset is a four-round panel survey and the data collection covered the years from 1991 to 1994. The primary objective of this Kagera Health and Development Survey (KHDS) was to estimate the economic impact of the death of prime-age adults on surviving household members. Thus, the research focused on the collection of detailed socioeconomic information from individuals who resided in a household in which one or more adult family members indicated they were in poor health at the time of the baseline (Ainsworth and Semali, 2001).

The sample of households was selected from a stratified random sample of communities from the 1988 Tanzanian census (stratified on agroclimatic zone and adult mortality rate). ${ }^{1}$ Within each community, the household sample was stratified according to the anticipated households' risk of suffering a prime-age adult death. Households were divided in "high-risk" or "low-risk" categories, based on information obtained from a houseto-house enumeration of all selected communities.

Altogether, 915 households were effectively interviewed at least once over the 4 waves of the survey, and up to a maximum of four times. ${ }^{2}$ Individuals belonging to the same household were defined as a group of people living and sharing meals together for at least 3 months in the last year (Ainsworth and Semali 2001). This survey collects information that makes it particularly appropriate for the purpose of our research, in particular the extensive information on household income and consumption and on individual's health status and anthropometrics. For the present analysis, which focuses on the children's nutritional status, we focus on the height, weight and demographic information of children aged 5 years or below and the characteristics of the households and community to which the children belong. Overall, the total sample of children surveyed amounts to 1140 different children, visited between one and four times and making up an unbalanced panel of 2871 personwave observations.

\footnotetext{
${ }^{1}$ Both the prevalence of HIV and adult mortality rates in Kagera were geographically concentrated, and, therefore are strongly correlated with different climates and cropping patterns. The region with the highest rural HIV infection rates was in the northeast $10 \%$ in Bukoba Rural and Muleba districts and 24\% in the town of Bukoba), where tree crops (bananas, coffee) were predominant. The regions with the lowest HIV infection rates were in the south and west $(0.4 \%$ in Ngara and Biharamulo districts), where perennial crops and livestock are more common (Killewo and others 1990). Thus, a survey design stratified only on mortality rates might confound the effects of high mortality with different agricultural, soil, and rainfall patterns.

${ }^{2}$ Some households dropped from the sample at each round and they were replaced. Out of the original sample, 6 percent of households dropped before their first interview. Out of the remaining sample of households, 10 percent dropped out of the remaining sample before the end of the survey (Ainsworth and Semali, 2001). The attrition rate compares favorably to other panel datasets.
} 


\section{Nutritional Status of Children in Kagera}

The nutritional status of a child is usually assessed with three indicators: stunting (low height for age), wasting (low weight for height) and underweight (low weight for age). All indicators are expressed in "z-scores" which are derived by comparing the child's height and weight with that of a "reference" group of well nourished children defined by the US National Center for Health Statistics (NCHS) (World Health Organization (WHO) 1995). More specifically the stunting z-score is the difference (expressed in standard deviations (SD)) of a child's height for age from the median height of children of the same age and sex in the reference population. The z-score is thus the conversion of the child's height into a standardized unit. Relatively short children have negative $z$ score; tall children a positive $z$ score. The commonly used cut-off point to identify severely malnourished children is a measurement of 2 SD below the median of the "reference" group. Thus, a child is "stunted" if his/her z-score- is below or equal to -2 .

Table 1 reports the descriptive statistics related to the sample. On average, 28 percent of children aged 0-5 are moderately underweight (i.e. their weight-for-age is more than two standard deviations below the median of the international "reference" population). Nearly 40 percent of the children are stunted but only 6 percent are malnourished according to the weight for height indicator. This is a general pattern; low height for age or low weight for age reflect long term cumulative deprivation while low weight for height indicates an acute crisis (Alderman, 2000). The former two measures being cumulative generally reveal more children outside of normal ranges than does the latter, which typically only shows high values during periods of acute food shortage. The WHO recommends stunting as a reliable measure of overall social deprivation (WHO, 1986), whereas the MDG nutritional indicator is defined as weight for age. In the remainder of the paper we concentrate on both stunting and being underweight.

Table 2 illustrates the nutrition problems for Tanzania. According to the 1999 DHS, 43 percent of children under five are stunted, 6 percent are wasted and 29 percent are underweight. Though we do not suggest that the Kagera data are representative of Tanzania, a comparison between Tables 1 and 2 shows that the nutritional pattern in Kagera is not very different from that found elsewhere in the country.

Figure 1 indicates that the probability of malnutrition declines with income. At low levels of income, more than $50 \%$ of children are malnourished. While this declines with 
income there is still substantial malnutrition over much of the range of income. Figure 2 gives a somewhat different perspective. In this figure the y axis indicates $\mathrm{Z}$ scores for height for age and weight for age respectively rather than the percentage below a cut-off line. While this confirms that nutrition improves with income, it also shows that children in communities with a nutrition intervention do better than children in other communities. This pattern is particularly pronounced at the lower end of the income range.

\section{Econometric Analysis and Results}

In this paper we explain in a reduced form regression the height / weight $\mathrm{z}$ score of children aged 0-5 years. The reduced form is based on a utility maximization over goods and health subject to a health production function and a budget constraint (see, among others, Glewwe et al. 2004). A general representation is as follows:

$$
\mathrm{M}_{\mathrm{it}}=\mathrm{a}+\mathrm{bX}_{\mathrm{it}}+\mathrm{gC}_{\mathrm{it}}+\mathrm{e}_{\mathrm{it}}
$$

Where:

$\mathrm{M}_{\mathrm{it}}$ is the malnutrition indicator of the child $\mathrm{i}$ at time $\mathrm{t}$, $\mathrm{X}_{\mathrm{it}}$ a vector of regressors comprising socio-economic variables at household level, $\mathrm{C}_{\mathrm{it}}$ is a vector of community related variables and $\mathrm{e}_{\mathrm{it}}$ an i.i.d. disturbance term.

The community related explanatory variables include a dummy variable indicating whether Partage or feeding posts are present in the village where the child resides. This variable is crucial to our analysis as it permits measurement of the effect of specific nutrition interventions. As mentioned, the paper assesses the presence of such programs in each community rather than the effective child's participation in the program. Therefore the coefficient relative to Partage / feeding post in a village should be interpreted as the impact on the (standardized) height or weight of a child due to the availability of a program in the village. A description of all other variables used in the model is presented in Table 3.

Plausibly, program placement is endogenous. If, for example, programs are placed in areas with greater malnutrition problems, or in areas where program success is more probable, the measured impact of programs may be biased. Moreover, the sign of any bias due to endogenous program placement is uncertain. If programs are placed where the 
village exhibits higher malnutrition rates stemming from unobserved factors the coefficient of program impact will be biased downward (Rosenzweig and Wolpin 1986, Pitt, Rosenzweig and Gibbons 1995). But if programs are placed in more potentially responsive villages an overestimation of program impacts is plausible.

Thus, while the analysis begins with an OLS estimation, this is compared to a preferred estimation strategy which allows for endogenous placement. While in many contexts the most convincing way to handle the issue of placement is to have site selection randomized. This is feasible in our case and other measures are employed to increase confidence that the results are plausible. Firstly, we show that adding community correlates to a simple model with only individual and household variables and an indicator variable reflecting the presence of a nutrition program as regressors along does not change the basic outcomes. Moreover, we show that if the model is run with the dependent variable being nutritional status of older children - those who passed through the most nutritionally

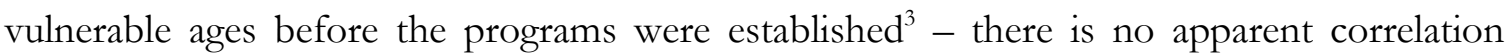
between the presence of programs and nutritional status. Were programs established in more responsive villages, or in villages where malnutrition is an especially serious problem, a significant correlation between these sites and nutritional status would be expected, even in the absence of causality. Finally, we offer an instrumental variables approach, our preferred methodology. Seldom are instruments above criticism - even with a range of diagnostic tests. However, the plausibility of the results is augmented by the comparison of the age specific OLS results, which confirm that there is no prexisiting relation between the sites eventually chosen for Partage and nutritional status

In the remainder of this section we will first discuss the results of the height for age regression. As the results for the weight for age regression are almost identical, we will only flag significant differences at the end of the section.

Note that because the dependent variable is expressed in standard deviations, coefficients of dummy variables can be interpreted as the SD change of setting the dummy to 1; for continuous variables the coefficient associated to each regressor are the SD change

\footnotetext{
${ }^{3}$ See Hoddinott and Kinsey (2001) for a discussion of age specific vulnerability as well as Shrimpton et al.(2001).
} 
in the dependent variable due to a unit increase of the regressor, while for variables expressed in logs they reflect the SD change of a doubling of the variable at hand.

\subsection{Specification I: OLS}

The first specification includes in addition to the nutrition intervention, household and individual specific variables to explain aged 0-5 children's nutritional status. The results are shown in column 1 of Table 4. Column 2 of Table 4 includes, in addition to household and individual variables, a set of characteristics of the community where the children reside. The coefficient associated with the program is, in both cases, significant, increasing from 0.26 to 0.29 (column 1 and 2, respectively) when the observable community characteristics are added. As an additional check of robustness of our results, we consider how older children respond to the program. As mentioned, the rationale for this is that older children were unlikely to benefit appreciably from the intervention when the program started. Column 3 of Table 4 reports the results for children aged 6 to 9. As anticipated, the programs do not correlate with nutritional status, but other variables do.

Returning to the results in column 2, consistent with the general literature (Shrimpton, et al. 2001), the age of the child has a strong non-linear impact on his/her nutritional status. To capture this effect, we include dummy variables that reflect different age categories. Compared to children aged one year or less (the omitted category), older children are more affected by nutritional problems. The nadir is reached for children aged between 3 and 4 years. Gender also matters for the height of a child. Girls perform better than boys in their height $z$-score, a result in line with the related literature (Svedberg, 1990).

The season during which a child is born also plays a role in determining his/her nutritional status. Being born during the rainy season -when labor demands and the burden of disease (malaria) are highest, has a negative effect on nutritional status. This effect is precisely estimated, but only for children who are less than 2 years old. The impact of the season of birth becomes insignificant later in the child's life.

Parental characteristics are important determinants of the child's health status. Both father's and mother's height have a positive and significant impact on the height of the child. This result suggests persistence in nutritional status across generations: improving the nutritional status of the current generation not only improves the welfare of the current 
generation, but also that of future generations as children born from taller parents are less likely to be malnourished themselves.

Our regressors also include whether the father and/or the mother has passed away. This captures differences in nutritional status between orphaned children and children whose parents are alive. The results suggest that it matters who passed away. Paternal orphans are shorter than children with a living father - a deficit of 0.32 standard deviations. Maternal orphans on the other hand, do not show a significant difference in their height compared to that of other children. Likewise, father's (but not mother's) educational attainment helps improve the nutritional status of the child. An additional year of education of the father increases a child's height by 0.03 SD.

Household income and the environment where the child resides are key variables in determining the resources and the attention to the physical and psychological growth of the child. With higher income levels households are able to buy additional food (Abdulai and Aubert, 2004) as well as increase their hygiene standards. This study uses per capita consumption instead of per capita income to measure the economic resources available to the household, as suggested by Deaton and Grosh (2000). The main reasons to do so are that per capita consumption is recorded more precisely than households income and it is a better proxy for permanent income than current income. The estimates of the impact of consumption on nutritional status are at the low end of the range found in the literature (Haddad et al. 2003). More specifically, a doubling of household per capita annual consumption would generate an increase of the height $z$-score of the child equivalent to 0.18 SD. Income composition plays an additional role. A higher incidence of farm income out of total income has negative consequences for a child's nutritional status -this effects is not very precisely estimated in the second column of Table 4, but is in our preferred random effects regression.

Community variables also influence nutrition status. For example, children living in a community near a motor road show a height z-score that is almost half a SD higher than their peers living in a village without a motor road. Vaccination contributes significantly and positively to nutritional status. Distance to the health facility and presence of a village health worker do not have an impact on nutritional status like whether or not the motor road is passable. The coefficient relative to the variable for living in urban areas is positive, but again not significant. 
Finally, the OLS results show that children in communities that have either a feeding posts or a Partage program or both are taller; they are almost 0.3 SD higher compared to the height of the children who live in communities without these programs. ${ }^{4}$

OLS estimates have also been performed on the underweight $z$ score of the child. In this case, the presence of a nutrition intervention in the community no longer has a significant impact on the (standardized) weight of the child (it does in the preferred specification discussed in the next section). Expenditures on the other hand, continue to have a positive and significant effect. A doubling of household per capita consumption would generate an increase of the weight z-score of about 0.15 SD. Nutritional status still worsens with age, though this effect is more tenuous than in the case of stunting. Finally in this regression maternal education has a positive effect. So whereas stunting responded positively to additional education of the father, the weight $z$-score is responsive to additional maternal education. An additional year of maternal education increases the weight for age zscore of the child by 0.02 SD.

\subsection{Instrumenting Program Placement and Observed Consumption.}

In seeking instruments to address the possibility of endogenous program placement it is necessary to find variables that have predictive power on the endogenous placement variables and, at the same time, are not correlated with the child's health output and the measurement errors present in the explanatory variables. The set of instruments used to model Partage and feeding posts include the average per capita household consumption in the village and the average height of adults aged 25-32 in the village as proxies for the average nutritional status of the village before Partage or other programs were started. The set of instruments also includes the main shocks each community experienced in the previous ten years, the main causes of adult and children death in the community where the child resides and whether the village has a daily market. ${ }^{5}$ Whether and which type of disasters happened in the past ten years presents the appropriate features for being used as an instrumental variable of the program placement. While such shocks impoverish the village it is arguable whether they affect the health of the children in a direct way rather than

\footnotetext{
${ }^{4}$ Different specifications to capture the effect of feeding posts on the nutritional status of the child were tried. In particular we explored whether the impact of the intervention on the child's health varied with different household income levels. However, the results did not provide evidence in support of this assumption

5 See notes to Table 5.
} 
through the increase in the probability of having a program placed in the village as well as through the included income, education, and community variables. We include tests to ascertain the validity of the proposed instruments.

The ancillary regression used to instrument the (endogenous) feeding post / Partage variable is reported in Table A1 in Appendix $1 .{ }^{6}$ The coefficient estimates show that the intervention targeted villages with worse conditions such as villages with a low ratio of vaccinated children. This suggests that, unless instrumented, the OLS coefficient associated with the presence of a program will be downward biased, a finding in line with recent empirical findings of Behrman, Cheng, and Todd (2004) and Attanasio and Vera-Hernandez (2004) who also evaluated the impact of a nutritional program participation on the health outcomes of children. Their evidence suggest that, without taking into account endogeneity, the impact of the program would be underestimated.

We also instrument per capita consumption to take into account measurement errors in per capita household consumption that could lead to attenuation bias towards zero. We use per capita household income and the quality of the roof of the house where the child resides as instruments. The use of income as an instrument does not, however, address the possibility that a child's health may affect income, possibly more through adult time allocation than the direct loss of child labor given the age of the children we are considering. The approach used here presumes that this is a minor issue relative to the problem of measurement error.

F-tests indicate that the proposed instruments have predictive power to explain the presence of programs and that they have no predictive power for malnutrition beyond their influence through the nutrition program variable. The latter test is based on regressing the height of the child on all regressors and instruments. This test allows to detect whether instruments have additional power on the current height of the child, beyond through the prediction of the program probability. The value associated to this $F$ test is 1.40 , suggesting that our instruments do not have a direct effect on malnutrition. Thus it is valid to exclude them from the malnutrition equation. ${ }^{7}$ The results of the instrumenting equation, which are

\footnotetext{
${ }^{6}$ As the placement of the program is at village level, the ancillary regression has been run on the sample based on the four round panel dataset made of village level observations; the dataset, thus, being different then the one used for our main regression.

${ }^{7}$ We also derived a chi squared test following Wooldridge (2001). According to the test result we cannot reject the overidentifying restrictions. Different set of instruments have been tried, the coefficient associated with Partage ranging from 0.3 to 1.2.
} 
shown Table 4, column 4, are similar in significance and in magnitude with the results in column 2. However, the presence of feeding posts or Partage has a much higher impact on nutritional status of children, once the endogeneity of the intervention is taken into account. This suggests that the OLS estimates (column 2) are downward biased.

Column 5 of Table 4 illustrates the sensitivity of the results to assumptions on the error structure. As indicated, the data set is a panel with multiple observations on individual children. The panel structure of the data allows us to perform a random-effect estimation strategy, which takes into account the unobserved individual specific component in the error term $\mathrm{e}_{\mathrm{it}}{ }^{8}$

The random effect estimation strategy also includes the steps to account for the endogeneity of the feeding posts and measurement errors in per capita consumption explained above. The coefficient associated with the presence of a program in the village where the child resides is now 0.44 .

To test which specification is the more appropriate, the pooled regression (column 2) or the regression taking into account unobserved heterogeneity through an individual random effect (column 5), we perform a Breusch and Pagan (1980) Lagrange multiplier test ${ }^{9}$ which tests the plausibility of imposing the assumption of equal variance in the individual error terms. The associated chi squared statistics is 1120, and we reject the null hypothesis that the data can be pooled. Thus, the random effect model is our preferred specification.

Table 5 shows the estimates related to the (standardized) weight for age of children living in Kagera. The coefficients are similar to those obtained for stunting, in size, sign and significance. It is worth noting, however, that in the weight for age regression mother's as well as father's education has a positive impact on the weight of the child, and the coefficients show an equal impact of the parents' education on the nutrition output of the child.

\section{Policy Implications}

In this section we use the models of Tables 4 and 5 to predict the declines in malnutrition that can be expected from a sustained annual increase in per capita income.

\footnotetext{
${ }^{8}$ A fixed effect approach is not feasible since it wipes out all information about the presence of nutrition interventions.
} 
Demombynes and Hoogeveen (2004) report that, if inequality remains unchanged, a 2.2\% annual increase in per capita income is sufficient to attain, for Tanzania, the income poverty MDG by 2015. We also explore to which degree income growth contributes to attaining the reduction of stunting and children being malnourished. We project forward from 1993 and allow for income growth and increases in the coverage of nutrition interventions from $12 \%$ of the households in the survey to an 32\% and 62\% (an additional 20\%,50\%) and complete coverage and consider the joint impact. As the models in Tables 4 and 5 estimate the $z$ score and not the fraction of children that is malnourished, the impact of growth and various interventions depend on (i) the size of the intervention and (ii) the distribution of the $z$ scores. As shown in Figure 3, the cumulative distribution functions for both height and weight for age are steepest near the cut-off point for malnutrition of -2 standard deviations. Consequently, malnutrition rates will be particularly sensitive to changes in z scores.

Table 6 illustrates the simulation results. It presents percentage changes relative to the baseline; the MDG objective is attained if a percentage change of $50 \%$ or more is made. If this is the case it is indicated in bold in the table. The second column shows reductions in income poverty. The other columns deal with changes in malnutrition resulting from various combinations of income growth and nutrition interventions. The results for income poverty in the second column suggest that to attain the income poverty MDG in Kagera, an annual rate of income growth $1.5 \%$ is needed. This is less than the growth rate of $2.2 \%$ suggested by the simulations of Demombynes and Hoogeveen (2004). The result is consistent because their simulations are for Tanzania as a whole for which in 1992 income poverty was $38.6 \%$, whereas ours are for Kagera where poverty was 25.9\% in 1992.

Table 6 also shows that even a relatively high per capita growth rate of $3 \%$ is insufficient to attain the nutrition MDG. Additional program coverage will contribute to reducing malnutrition, but only a combination of (almost) universal program coverage with per capita income growth adequate to reach the poverty goal is sufficient to halve malnutrition by 2015. The final three columns in the Table show how other changes associated with per capita income growth will contribute to attaining the nutrition MDG. A reduction in the importance of farm income to at most $75 \%$ of total household income, will contribute an additional $2 \%$ malnutrition reduction; a motor road in every village reduces

\footnotetext{
${ }^{9}$ See also Baltagi (2001) on this test
} 
malnutrition by another 5\%; an additional year of education for the father will add another $8 \%$, and increasing the ratio of vaccinated children to $95 \%$ will decrease malnutrition rates by $10 \%$. In combination these changes are non-negligible. If, per capita income growth can be kept at $2.5 \%$ (as has been the case in most recent years), and if this growth is associated with improvements in education, roads and less dependency on farm income, interventions in at least $50 \%$ of the communities would still be required to attain the MDG.

\section{Conclusions}

A combination of income growth and nutrition interventions is often said to be needed to adequately tackle malnutrition, yet evidence to support this claim is not generally available. This paper evaluates the joint contribution of income growth and nutrition interventions towards the reduction of malnutrition in Tanzania. The paper also considers other determinants of malnutrition. Our results confirm that parental education and access to health care - as proxied by the fraction of vaccinated children in the community - matter. It also shows that stunting is a cumulative process; thus, underscoring the importance of ensuring adequate nutrition from very early childhood onward. Most importantly we find that both income growth and the presence of nutrition programs in the community contribute positively and significantly to the reduction of malnutrition.

To investigate whether income growth, nutrition interventions or a combination of both are required to attain the nutrition MDG, we carried out a series of policy simulations. We find that income growth alone is insufficient to attain the MDG benchmark for nutrition. The same holds for nutrition interventions that reach less than half the population. Only the combination of income growth at the household level with large scale nutrition interventions is shown to be sufficient to bring about the desired results. ${ }^{10}$

\footnotetext{
10 There is another reason, why income growth is required to bring about a reduction in malnutrition: it provides the only sustainable basis for increased revenue collection from which nutrition interventions could be paid.
} 
Finally, this study shows that nutrition interventions are able to substantially contribute to the reduction of malnutrition. In showing this, the paper fills an important gap as impact evaluations of nutrition interventions are scarce (see Mkenda 2004 for a review for Tanzania). Even the much studied Iringa project is inconclusive about the effectiveness of various strategies such as growth monitoring and promotion, integrated care and nutrition, communications for behavioral change, supplementary feeding for women and young children, school feeding, health related services, micronutrient supplementation and foodbased strategies (Allen and Gillespie 2001). Though our study suggests that the described interventions are effective, their (cost)-effectiveness remains an unknown. A recent review on cost effectiveness suggests that some interventions are more cost effective than others, particularly vitamin A supplementation for children under age five, iron supplementation for pregnant women, and some types of nutrition education and behavioral change (Gillespie and Haddad 2001; Behrman, Alderman and Hoddinott, 2004). In this light it is of importance to take the next step and to assess the cost effectiveness of the programs considered in this paper.

\section{References}

Ainsworth M. and I. Semali, (2001), “The impact of Adult Death on Children's Health in Northwestern Tanzania”, World Bank working paper, n. 2266.

Abdulai A. and D. Aubert. (2004). A Cross-Section Analysis of Household Demand for Food and Nutrients in Tanzania. Agricultural Economics .

Alderman H. (2000), “Anthropometry”, in Designing Household Survey Questionnaires for Developing Countries in Glewwe P. and M. Grosh, vol.1

Allen, L., and S. Gillespie, (2001), "What Works? A Review of Efficacy and Effectiveness of Nutrition Interventions". Asian Development Bank, Nutrition and Development Series \# 5, Manila.

Arellano, M. and S. Bond. (1991). Some tests of specification for panel data: Monte Carlo evidence and an application to employment equations. The Review of Economic Studies 58: 277-297.

Attanasio O. and A.M. Vera-Hernandez (2004), "Medium and Long Run Effects of Nutrition and Child Care: Evaluation of a Community Nursery Programme in Rural Colombia", unpublished paper

Baltagi B.H. (2001), "Econometric Analysis of Panel Data”, Chichester ; New York : John Wiley, 2001. 
Behrman J., H. Alderman, and J, Hoddinott, (2004), “Hunger and Malnutrition”. In Bjorn Lomborg (ed.) Global Crises, Global Solutions. Cambridge (UK): Cambridge University Press.

Behrman J., Cheng Y. and P.E. Todd (2004), "Evaluating Preschool Programs when Length of Exposure to the Program Varies: A Non Parametric Approach", The Review of Economics and Statistics, vol.86, no1: 108-132

Breusch, T. S. and Pagan, A. R., (1980), The Lagrange Multiplier Test and Its Applications to Model Specification in Econometrics, Review of Economic Studies, vol. 47, n1, pp. 23953

Christiaensen L. and H. Alderman, (2004), "Child Malnutrition in Ethiopia: Can Maternal Knowledge augment the Role of Income?", Economic Development and Cultural Change, vol. 52, n.2, pp. 287-312

Deaton, A. and M. Grosh (2000); "Designing household survey questionnaires for developing countries: Lessons from fifteen years of the Living Standards Measurement Study". Volume 1, pp. 91-133, Washington, D.C.: World Bank

EDI 2004. Kagera Rural CWIQ. Baseline Survey on Poverty, Welfare and Services in Kagera Rural Districts.

Demombynes G. and J. G. Hoogeveen 2004. Growth, Inequality and Simulated Poverty Paths for Tanzania, 1992-2002, World Bank Policy Research Paper No. 3432. World Bank. Washington DC.

de Onis M, Blössner M, Borghi E, Frongillo EA, Morris R. 2004. "Estimates of global prevalence of childhood underweight in 1990 and 2015", Journal of the American Medical Association: no.291, pp.2600-6.

Gillespie and Haddad 2001, "Effective Food and Nutrition Policy Responses to HIV/AIDS: What We Know and What We Need to Know", Journal of International Development v13, n4, pp. 487-511

Glewwe P., S. Koch and Nguyen B. L., (2004), "Child Nutrition, Economic Growth and the Provision of Health Care Services in Vietnam", in Economic Growth, Poverty, and Household Welfare in Vietnam, ed. Glewwe P., N. Agrawal and D. Dollar, World Bank.

Haddad, Lawrence., Harold Alderman, Simon Appleton, Lina Song, and Yisehac Yohannes. (2003), "Reducing Child Malnutrition: How Far Does Income Growth Take Us?" World Bank Economic Review, 17(1): 107-131

Heckman J., Lalonde, R., and Smith, J. (1999). “The Economics and Econometrics of Active Labor Market Programs”. In O. Ashenfelter, \& D. Card (Eds.), Handbook of Labor Economics (Vol. 3A, pp. 1865-2097). Amsterdam: Elsevier Science.

Hoddinott, J. and B. Kinsey, 2001. "Child growth in the time of drought". Oxford Bulletin of Economics and Statistics 63: 409-436

Killewo J. and others. 1990. "Prevalence of HIV-1 Infection in the Kagera Region of Tanzania: A Population-Based Study". AIDS 4 (11): 1,081-85.

Mkenda A.E. (2004), “The Benefits of Malnutrition Interventions: Empirical Evidence and Lessons to Tanzania”, unpublished paper, World Bank. 
Pitt M., Rosenzweig M.R. and D.M. Gibbons. (1995) "The Determinants and Consequences of the Placement of Government Programs in Indonesia", in van de Walle D. and N. Kimberly, eds. Public spending and the poor: Theory and evidence pp. 114-49

REPOA 2004. “Trends in Malnutrition in Tanzania”. Mimeo.

Rosenzweig, M. R. and W. Kenneth, (1986), "Evaluating the Effects of Optimally Distributed Public Programs: Child Health and Family Planning Interventions", American Economic Review v76, n3, pp. 470-82

Quisumbing A. R. (2003). "Food Aid and Child Nutrition in Rural Ethiopia", World Development, Vol. 31(7): 1309-1324.

Shrimpton R., Victora C., de Onis M., Costa Lima R., Blössner M., and G. Clugston. 2001. Worldwide Timing of Growth Faltering: Implications for Nutritional Interventions Pediatrics, 107(5): e75-81.

Svedberg, P., (1990) “Undernutrition in Sub-Saharan Africa: Is There a Gender Bias?” Journal of Development Studies, v26, n3 (April 1990): 469-86

UNICEF 2001. Women and Children in Tanzania, Dar es Salaam, 1990.

United Republic of Tanzania, National Bureau of Statistics [2002], Household Budget Survey 2000/01.

United Republic of Tanzania, President's Office 2003. Economic Survey 2003.

Yamano T, H. Alderman and L. Christaensen, Forthcoming. "Child Growth, Shocks, and Food Aid in Rural Ethiopia", American Journal of Agricultural Economics.

Wooldridge, J. Econometric Analysis of Cross Section and Panel Data. Cambridge, MA: MIT Press, 2002.

WHO (World Health Organization) 1995. Physical Status: The Use and Interpretation of Anthropometry, WHO Technical Report, No.854, Geneva

WHO (World Health Organization) 1986, Use and Interpretation of anthropometric indicators of nutritional status, Bulletin of the WHO, Geneva. 
Figure 1. Household income and the fraction of malnourished children (0-5 years)

Fraction of stunted children

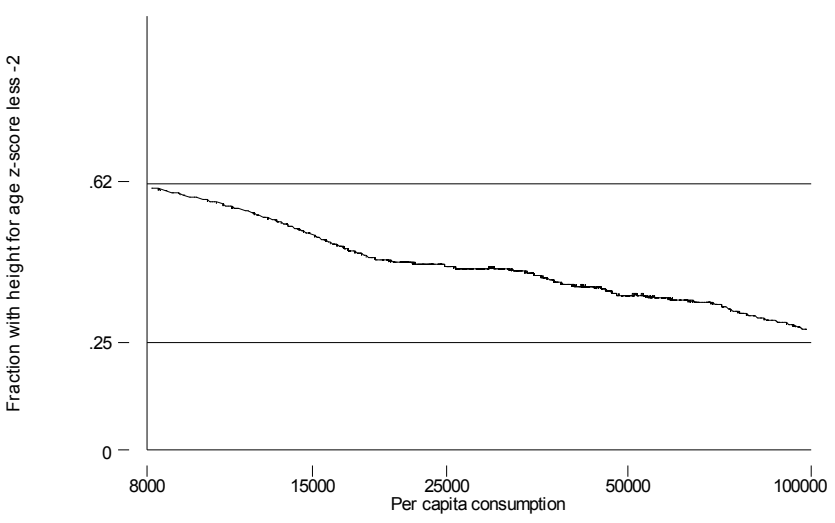

Fraction of underweight children

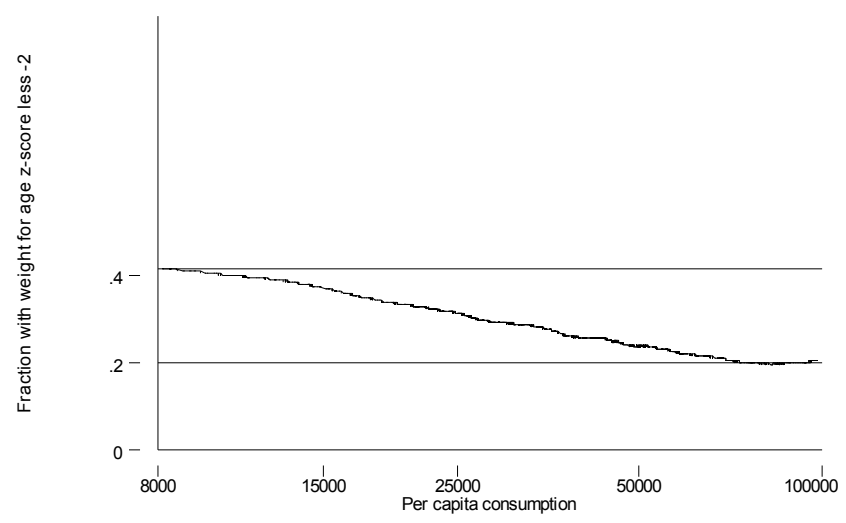

Figure 2. Nutrition z-scores for children aged 0-5 and presence of program interventions in the community

Weight for age z-scores

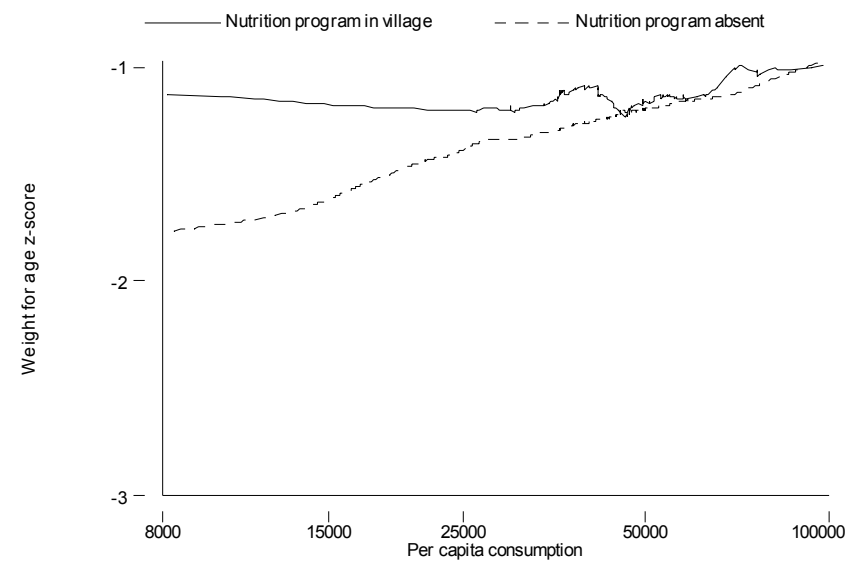

Height for age z-scores

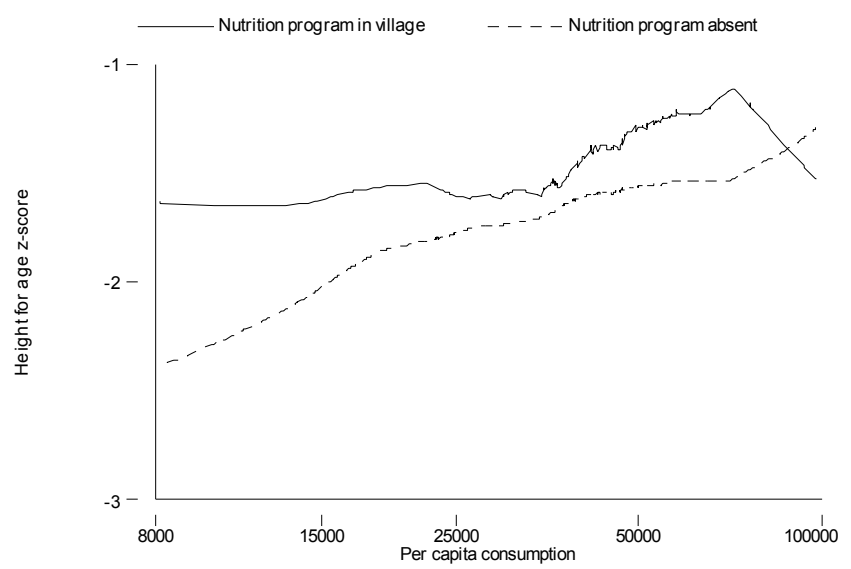


Figure 3. Cumulative density functions of nutrition z-scores for children aged 0-5 years

Stunted children

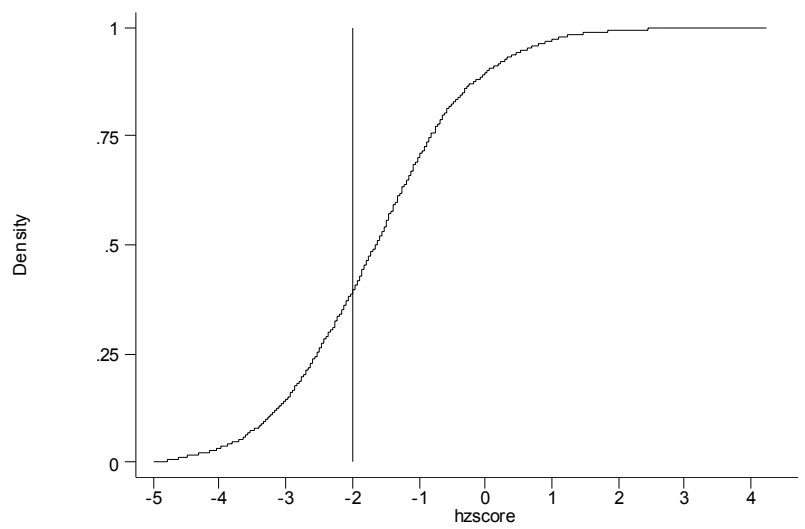

Underweight children

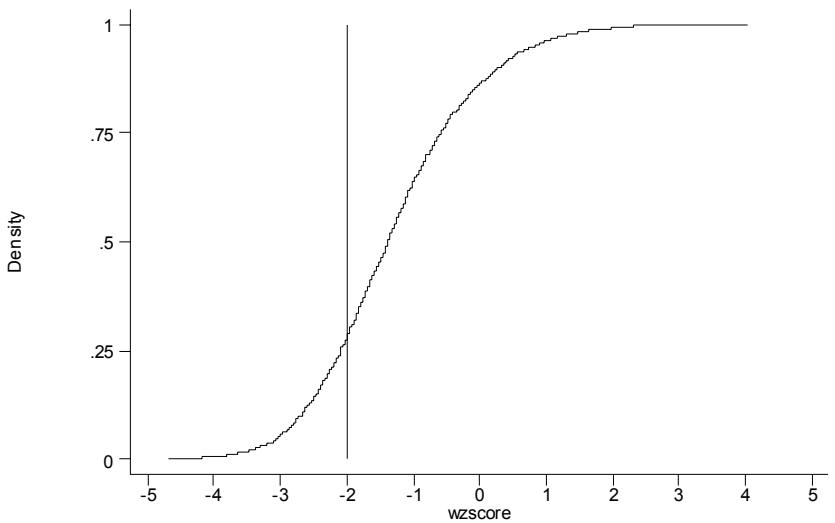


Table 1. Nutritional status of children in Kagera region, Tanzania. 1991-1994

\begin{tabular}{lccc}
\hline & \multicolumn{3}{c}{ Percentage of children whose z-score is below -1 SD } \\
\hline \multirow{3}{*}{ female } & Height for age & Weight for age & Weight for height \\
\cline { 2 - 4 } Male & 0.68 & 0.62 & 0.26 \\
Total & 0.72 & 0.65 & 0.29 \\
\hline \multicolumn{4}{c}{ fercentage of children whose z-score is below -2 SD } \\
\hline female & 0.70 & 0.63 & 0.05 \\
Male & 0.35 & 0.30 & 0.060 \\
Total & 0.43 & 0.28 & 0.06 \\
\hline
\end{tabular}

Note: For Kagera region the DHS data in 1996 report $42 \%$ of kids under five stunting, 36\% under-weight and 11\% wasting. (The percentage reflect those children whose z-score are below -2)

Source: Kagera Health and Development Survey (KHDS).

Table 2. Nutritional Status in Tanzania for Children Under-Five

\begin{tabular}{lccc}
\hline & \multicolumn{3}{c}{ Percentage of children whose Height $z$-score is below -2 SD } \\
\hline & Height for age & Weight for age & Weight for height \\
\cline { 2 - 4 } $1991-92$ & 0.43 & 0.29 & 0.06 \\
1996 & 0.44 & 0.31 & 0.07 \\
1999 & 0.43 & 0.29 & 0.06 \\
\hline
\end{tabular}

Source: REPOA (2004), calculated using DHS 1991/92, DHS 1996 and TRCHS 1999. 
Table 3. Description of the variable used and descriptive statistics, Kagera region, 1991-1994

\begin{tabular}{|c|c|c|c|}
\hline Variables & Definitions of Variables & Mean & $\begin{array}{l}\quad \text { Stan } \\
\text { dard } \\
\text { Deviation }\end{array}$ \\
\hline \multicolumn{4}{|c|}{ Community variables } \\
\hline Partage or feeding posts & $\begin{array}{l}=1 \text { if there is Partage and/or feeding post in the } \\
\text { village }\end{array}$ & 0.120 & 0.325 \\
\hline Urban & $=1$ if the child lives in a rural area & 0.163 & 0.370 \\
\hline Health worker & $=1$ if there is a health worker in the village & 0.818 & 0.386 \\
\hline Distance to health center & Distance to the nearest health center in $\mathrm{km}$ & 3.131 & 3.495 \\
\hline Motoroad & $=1$ if there is a motor road in the village & 0.954 & 0.210 \\
\hline Road impassable & $=1$ if the road is often impassable & 0.483 & 0.500 \\
\hline Ratio of children vaccinated & $\begin{array}{l}\text { Ratio of } 0 \text { to } 3 \text { year old children in the community } \\
\text { who have been vaccinated }\end{array}$ & 0.712 & 0.212 \\
\hline \multicolumn{4}{|c|}{ Individual and household characteristics } \\
\hline Height for age $z$-score & Height for age $z$ score statistics & -1.643 & 1.388 \\
\hline Weight for age $z$-score & Weight for age $z$ score statistics & -1.293 & 1.221 \\
\hline Aged 12_23 months & $=1$ if Child's age id between 12 and 23 months & 0.171 & 0.377 \\
\hline Aged 24_35 months & $=1$ if Child's age is between 24 and 35 months & 0.169 & 0.375 \\
\hline Aged 36_47 months & $=1$ if Child's age is between 36 and 47 months & 0.186 & 0.389 \\
\hline Aged48or more months & $=1$ if Child's age is 48 months or more & 0.308 & 0.462 \\
\hline Born in rainy season, aged $<2$ & Born in a rainy season and aged less than 2 & 0.251 & 0.434 \\
\hline Born in rainy season, aged $>2$ & Born in a rainy season and aged more than 2 & 0.508 & 0.500 \\
\hline Farm income/total income & Farm income as fraction of total household income & 0.687 & 0.245 \\
\hline Log per capita consumption & Log of per capita consumption & 10.483 & 0.609 \\
\hline Father dead & $=1$ if Father dead & 0.125 & 0.331 \\
\hline Mother dead & $=1$ if Mother dead & 0.041 & 0.197 \\
\hline Male & $=1$ if male & 0.523 & 0.500 \\
\hline Household size & Number of household's member & 8.992 & 4.315 \\
\hline Father's height & Father's height $(\mathrm{cm})$ & 168.835 & 5.387 \\
\hline Mother's height & Mother's height $(\mathrm{cm})$ & 158.522 & 5.790 \\
\hline Father's height missing & $=1$ if Father's height missing & 0.380 & 0.485 \\
\hline Mother's height missing & $=1$ if Mother's height missing & 0.149 & 0.357 \\
\hline Father's year of education & Father's year of education & 6.158 & 2.031 \\
\hline Mother's year of education & Mother's year of education & 5.191 & 2.681 \\
\hline \multicolumn{4}{|c|}{ Instruments } \\
\hline Mean log per capita consumption & Mean log per capita consumption in the village & 10.528 & 0.344 \\
\hline Crop Disaster & $\begin{array}{l}=1 \text { if crop damage was the main disaster in the past } \\
\text { ten years in the village }\end{array}$ & 0.080 & 0.268 \\
\hline Drought disaster & $\begin{array}{l}=1 \text { if drought was the main disaster in the past ten } \\
\text { years in a village }\end{array}$ & 0.356 & 0.479 \\
\hline Daily Market in Community & $=1$ if there is a daily market where the child resides & 0.616 & 0.486 \\
\hline AIDS main adults' death cause & $\begin{array}{l}=1 \text { if AIDS is the main cause of adults' death in the } \\
\text { village }\end{array}$ & 0.480 & 0.500 \\
\hline Mean male height & Average male height of adults aged $25-32$ & 169.284 & 3.985 \\
\hline Mean female height & Average female height of adults aged $25-32$ & 158.09 & 2.851 \\
\hline Good roof in the house & $=1$ if the child lives in a house with good roof & 0.638 & 0.481 \\
\hline $\begin{array}{l}\text { Mean (log) per capita income in } \\
\text { the village }\end{array}$ & Log of per capita income & 10.224 & 0.724 \\
\hline
\end{tabular}


Table 4. Regression results. Dependent variable: Height for age $\mathrm{z}$ score

\begin{tabular}{|c|c|c|c|c|c|}
\hline & $\begin{array}{c}\text { (1) } \\
\text { OLS } \\
\text { Individual } \\
\text { and } \\
\text { household } \\
\text { variables } \\
\end{array}$ & $\begin{array}{c}\text { (2) } \\
\text { OLS } \\
\text { Individual, } \\
\text { household } \\
\text { and } \\
\text { community } \\
\text { variables }\end{array}$ & $\begin{array}{c}\text { (3) } \\
\text { OLS. } \\
\text { Children 6-9 }\end{array}$ & $\begin{array}{c}(4) \\
\text { Instrumental } \\
\text { Variable } \\
\text { Regression } \\
\end{array}$ & $\begin{array}{c}(5) \\
\text { Individual } \\
\text { Random } \\
\text { Effect with } \\
\text { instruments }\end{array}$ \\
\hline & \multicolumn{5}{|c|}{ Community Variables } \\
\hline Partage or feeding posts & $\begin{array}{c}0.256 \\
(2.30)^{* *}\end{array}$ & $\begin{array}{c}0.286 \\
(2.68)^{* *}\end{array}$ & $\begin{array}{c}-0.016 \\
(0.16)\end{array}$ & $\begin{array}{c}0.543 \\
(1.83)^{*}\end{array}$ & $\begin{array}{l}0.437 \\
(1.90)^{*}\end{array}$ \\
\hline Urban & & $\begin{array}{l}0.169 \\
(1.25)\end{array}$ & $\begin{array}{l}0.060 \\
(0.34)\end{array}$ & $\begin{array}{l}0.170 \\
(1.18)\end{array}$ & $\begin{array}{c}0.247 \\
(2.68)^{* * *}\end{array}$ \\
\hline Health worker in the village & & $\begin{array}{l}-0.052 \\
(0.72)\end{array}$ & $\begin{array}{l}-0.158 \\
(1.60)\end{array}$ & $\begin{array}{l}-0.008 \\
(0.10)\end{array}$ & $\begin{array}{l}0.000 \\
(0.00)\end{array}$ \\
\hline $\begin{array}{l}\text { Minimum distance to the closest } \\
\text { health center }\end{array}$ & & 0.012 & 0.014 & 0.017 & 0.007 \\
\hline Is motorable road near & & $\begin{array}{c}(0.83) \\
0.488 \\
(4.46)^{* * *}\end{array}$ & $\begin{array}{c}(0.74) \\
0.432 \\
(3.42)^{* * *}\end{array}$ & $\begin{array}{c}(1.09) \\
0.482 \\
(3.85)^{* * *}\end{array}$ & $\begin{array}{c}(0.91) \\
0.510 \\
(2.94)^{* * *}\end{array}$ \\
\hline Road impassable & & $\begin{array}{c}-0.005 \\
(0.05)\end{array}$ & $\begin{array}{c}-0.114 \\
(0.89)\end{array}$ & $\begin{array}{c}-0.032 \\
(0.27)\end{array}$ & $\begin{array}{c}-0.051 \\
(0.68)\end{array}$ \\
\hline \multirow[t]{2}{*}{ Ratio of children vaccinated } & & $\begin{array}{c}0.650 \\
(3.99)^{* * *}\end{array}$ & 0.041 & $\begin{array}{c}0.700 \\
(3.52)^{* * *}\end{array}$ & $\begin{array}{c}0.222 \\
(2.10)^{* *}\end{array}$ \\
\hline & \multicolumn{5}{|c|}{ Household and individual variables } \\
\hline Log per capita consumption & $\begin{array}{c}0.206 \\
(3.95)^{* * *}\end{array}$ & $\begin{array}{c}0.184 \\
(3.55)^{* * *}\end{array}$ & $\begin{array}{c}0.154 \\
(1.96)^{*}\end{array}$ & $\begin{array}{c}0.207 \\
(2.52)^{* *}\end{array}$ & $\begin{array}{c}0.103 \\
(2.48)^{* *}\end{array}$ \\
\hline Farm income/total income & $\begin{array}{l}-0.322 \\
(2.11)^{* *}\end{array}$ & $\begin{array}{r}-0.215 \\
(1.36)\end{array}$ & $\begin{array}{c}-0.517 \\
(2.83)^{* * *}\end{array}$ & $\begin{array}{l}-0.175 \\
(1.02)\end{array}$ & $\begin{array}{l}-0.160 \\
(1.79)^{*}\end{array}$ \\
\hline Household size & $\begin{array}{r}-0.008 \\
(0.86)\end{array}$ & $\begin{array}{l}-0.005 \\
(0.64)\end{array}$ & $\begin{array}{c}-0.030 \\
(2.96)^{* * *}\end{array}$ & $\begin{array}{c}-0.008 \\
(0.85)\end{array}$ & $\begin{array}{l}-0.006 \\
(0.88)\end{array}$ \\
\hline Aged 12_23 months & $\begin{array}{c}-1.118 \\
(11.89)^{* * *}\end{array}$ & $\begin{array}{l}-1.189 \\
(13.06)^{* * *}\end{array}$ & & $\begin{array}{l}-1.186 \\
(13.00)^{* * *}\end{array}$ & $\begin{array}{l}-1.156 \\
(19.77)^{* * *}\end{array}$ \\
\hline Aged 24_35 months & $\begin{array}{l}-1.233 \\
(7.65)^{* * *}\end{array}$ & $\begin{array}{l}-1.238 \\
(8.12)^{* * *}\end{array}$ & & $\begin{array}{l}-1.236 \\
(8.14)^{* * *}\end{array}$ & $\begin{array}{c}-1.257 \\
(12.57)^{* * *}\end{array}$ \\
\hline Aged 36_47 months & $\begin{array}{c}-1.468 \\
(9.66)^{* * *}\end{array}$ & $\begin{array}{c}-1.479 \\
(9.94)^{* * *}\end{array}$ & & $\begin{array}{c}-1.482 \\
(9.89)^{* * *}\end{array}$ & $\begin{array}{c}-1.510 \\
(14.76)^{* * *}\end{array}$ \\
\hline Aged 48 or more months & $\begin{array}{c}-1.255 \\
(8.68)^{* * *}\end{array}$ & $\begin{array}{c}-1.257 \\
(8.76)^{* * *}\end{array}$ & & $\begin{array}{c}-1.259 \\
(8.70)^{* * *}\end{array}$ & $\begin{array}{c}-1.438 \\
(13.84)^{* * *}\end{array}$ \\
\hline Aged 8 years & & & $\begin{array}{l}0.034 \\
(0.48)\end{array}$ & & \\
\hline Aged 9 years & & & $\begin{array}{r}-0.036 \\
(0.51)\end{array}$ & & \\
\hline \multirow[t]{2}{*}{$\begin{array}{l}\text { Born in rainy season and aged } \\
\text { less than } 2\end{array}$} & -0.238 & -0.197 & & -0.198 & -0.419 \\
\hline & $(2.24) * *$ & $(1.79)^{*}$ & & $(1.78)^{*}$ & $(4.58)^{* * *}$ \\
\hline \multirow[t]{2}{*}{$\begin{array}{l}\text { Born in rainy season and aged } \\
\text { more than } 2\end{array}$} & -0.008 & -0.035 & & -0.029 & -0.178 \\
\hline & $(0.07)$ & $(0.29)$ & & $(0.24)$ & $(1.93)^{*}$ \\
\hline Father dead & $\begin{array}{c}-0.289 \\
(2.36)^{* *}\end{array}$ & $\begin{array}{c}-0.324 \\
(2.65)^{* *}\end{array}$ & $\begin{array}{l}-0.295 \\
(2.47) * *\end{array}$ & $\begin{array}{l}-0.316 \\
(2.49) * *\end{array}$ & $\begin{array}{c}-0.178 \\
(2.03)^{* *}\end{array}$ \\
\hline Mother dead & $\begin{array}{l}0.142 \\
(0.60)\end{array}$ & $\begin{array}{l}0.172 \\
(0.74)\end{array}$ & $\begin{array}{c}-0.038 \\
(0.26)\end{array}$ & $\begin{array}{l}0.161 \\
(0.68)\end{array}$ & $\begin{array}{l}0.099 \\
(0.81)\end{array}$ \\
\hline Male & $\begin{array}{c}-0.242 \\
(3.63)^{* * *}\end{array}$ & $\begin{array}{c}-0.249 \\
(3.59)^{* * *}\end{array}$ & $\begin{array}{l}-0.118 \\
(1.35)\end{array}$ & $\begin{array}{c}-0.254 \\
(3.66)^{* * *}\end{array}$ & $\begin{array}{c}-0.301 \\
(4.42)^{* * *}\end{array}$ \\
\hline Father's height & 0.043 & 0.042 & 0.031 & 0.041 & 0.038 \\
\hline
\end{tabular}




\begin{tabular}{lccccc} 
& $(5.61)^{* * *}$ & $(5.59)^{* * *}$ & $(3.74)^{* * *}$ & $(5.48)^{* * *}$ & $(5.74)^{* * *}$ \\
Mother's height & 0.039 & 0.038 & 0.034 & 0.038 & 0.039 \\
& $(4.23)^{* * *}$ & $(4.03)^{* * *}$ & $(3.44)^{* * *}$ & $(3.79)^{* * *}$ & $(6.22)^{* * *}$ \\
Father's height missing & 0.110 & 0.059 & 0.239 & 0.057 & -0.029 \\
& $(1.31)$ & $(0.71)$ & $(1.74)^{*}$ & $(0.68)$ & $(0.36)$ \\
Mother's height missing & -0.034 & 0.039 & -0.095 & 0.039 & 0.118 \\
& $(0.25)$ & $(0.30)$ & $(0.71)$ & $(0.29)$ & $(1.10)$ \\
Mother's years of education & 0.011 & 0.000 & -0.014 & 0.002 & 0.000 \\
& $(0.78)$ & $(0.01)$ & $(0.71)$ & $(0.14)$ & $(0.00)$ \\
Father's years of education & 0.032 & 0.029 & 0.032 & 0.032 & 0.036 \\
& $(2.04)^{* *}$ & $(1.85)^{*}$ & $(2.05)^{* *}$ & $(2.03)^{* *}$ & $(2.74)^{* * *}$ \\
Constant & -16.292 & -16.122 & -14.757 & -16.441 & -14.533 \\
& $(9.43)^{* * *}$ & $(8.28)^{* * *}$ & $(7.04)^{* * *}$ & $(9.19)^{* * *}$ & $(9.60)^{* * *}$ \\
Observations & 2984 & 2871 & 1357 & 2871 & 2871 \\
R-squared & 0.21 & 0.22 & 0.12 & 0.22 & \\
\hline
\end{tabular}

Note: Absolute value of $\mathrm{t}$ statistics in parentheses. ${ }^{*}$ indicates significance at $10 \%$ level; ${ }^{* *}$ at $5 \%$ and ${ }^{* * *}$ significant at $1 \%$ level of confidence. Columns 4 and 5 use predicted values of $\log$ of per capita consumption and feeding posts to deal with the endogeneity and measurement error problems associated to their variables. The Partage / feeding post variable is a community level variable. Consequently the set of instruments are community variables. They include: mean of the (log) household expenditures, drought and crop disaster in the past ten years, presence of a daily market on community, AIDS being a main cause for adult mortality and average female and male height for those aged 25-32. The Partage / feeding post variable was then regressed on the instruments listed here and other community variables in the model. Log per capita consumption is instrumented with log income and the presence of a good (wood, iron sheets, concrete, asbestos) roof in the house. Predicted per capita consumption was then obtained after regressing log per capita expenditure on its instruments and the various community and household regressors. Standard errors corresponding to T-statistics in columns 4 and 5 are obtained by using the bootstrapping method, required because of the complication of instrumenting community variables. The total number of different individuals observed between 1 and 4 times is 1206. 
Table 5. Regression results. Dependent variable: Weight for age

\begin{tabular}{|c|c|c|c|c|c|}
\hline & $\begin{array}{c}(1) \\
\text { OLS } \\
\text { Individual } \\
\text { and } \\
\text { household } \\
\text { variables }\end{array}$ & $\begin{array}{c}(2) \\
\text { OLS } \\
\text { Individual, } \\
\text { household } \\
\text { and } \\
\text { community } \\
\text { variables }\end{array}$ & $\begin{array}{c}\text { (3) } \\
\text { OLS. } \\
\text { Children 6-9 }\end{array}$ & $\begin{array}{c}(4) \\
\text { Instrumental } \\
\text { Variable } \\
\text { Regression }\end{array}$ & $\begin{array}{c}(5) \\
\text { Individual } \\
\text { Random } \\
\text { Effect with } \\
\text { instruments }\end{array}$ \\
\hline & \multicolumn{5}{|c|}{ Community Variables } \\
\hline Partage or feeding posts & $\begin{array}{l}0.130 \\
(1.11)\end{array}$ & $\begin{array}{l}0.158 \\
(1.30)\end{array}$ & $\begin{array}{c}-0.102 \\
(0.88)\end{array}$ & $\begin{array}{c}0.553 \\
(1.88)^{*}\end{array}$ & $\begin{array}{c}0.456 \\
(2.14)^{* *}\end{array}$ \\
\hline Urban & & $\begin{array}{c}-0.020 \\
(0.16)\end{array}$ & $\begin{array}{l}-0.002 \\
(0.01)\end{array}$ & $\begin{array}{l}-0.019 \\
(0.15)\end{array}$ & $\begin{array}{l}0.072 \\
(0.86)\end{array}$ \\
\hline Health worker in the village & & $\begin{array}{l}0.084 \\
(1.23)\end{array}$ & $\begin{array}{l}-0.061 \\
(0.57)\end{array}$ & $\begin{array}{c}0.145 \\
(2.32)^{* *}\end{array}$ & $\begin{array}{l}0.080 \\
(1.63)\end{array}$ \\
\hline \multirow[t]{2}{*}{$\begin{array}{l}\text { Minimum distance to the closest } \\
\text { health center }\end{array}$} & & 0.003 & 0.012 & 0.011 & 0.006 \\
\hline & & $(0.31)$ & $(0.79)$ & $(0.98)$ & $(0.76)$ \\
\hline Is motorable road near & & $\begin{array}{c}0.496 \\
(5.81)^{* * *}\end{array}$ & $\begin{array}{c}0.415 \\
(3.91)^{* * *}\end{array}$ & $\begin{array}{c}0.478 \\
(6.18)^{* * *}\end{array}$ & $\begin{array}{c}0.553 \\
(3.53)^{* * *}\end{array}$ \\
\hline Road impassable & & $\begin{array}{r}-0.131 \\
(1.54)\end{array}$ & $\begin{array}{c}-0.142 \\
(1.33)\end{array}$ & $\begin{array}{l}-0.167 \\
(2.04)^{* *}\end{array}$ & $\begin{array}{l}-0.196 \\
(2.89)^{* * *}\end{array}$ \\
\hline \multirow[t]{2}{*}{ Ratio of children vaccinated } & & $\begin{array}{c}0.310 \\
(2.36)^{* *}\end{array}$ & $\begin{array}{l}0.002 \\
(0.01)\end{array}$ & $\begin{array}{c}0.398 \\
(2.67)^{* *}\end{array}$ & $\begin{array}{c}0.166 \\
(1.65)^{*}\end{array}$ \\
\hline & \multicolumn{5}{|c|}{ Household and individual variables } \\
\hline Log per capita consumption & $\begin{array}{c}0.209 \\
(4.19)^{* * *}\end{array}$ & $\begin{array}{c}0.170 \\
(3.38)^{* * *}\end{array}$ & $\begin{array}{c}0.142 \\
(2.32)^{* *}\end{array}$ & $\begin{array}{c}0.209 \\
(3.59)^{* * *}\end{array}$ & $\begin{array}{c}0.117 \\
(2.98)^{* * *}\end{array}$ \\
\hline Farm income/total income & $\begin{array}{l}-0.340 \\
(2.37)^{* *}\end{array}$ & $\begin{array}{l}-0.335 \\
(2.40)^{* *}\end{array}$ & $\begin{array}{l}-0.359 \\
(2.51)^{* *}\end{array}$ & $\begin{array}{l}-0.281 \\
(1.91)^{*}\end{array}$ & $\begin{array}{l}-0.163 \\
(1.93)^{*}\end{array}$ \\
\hline Household size & $\begin{array}{l}0.004 \\
(0.60)\end{array}$ & $\begin{array}{l}0.004 \\
(0.63)\end{array}$ & $\begin{array}{l}-0.016 \\
(1.74)^{*}\end{array}$ & $\begin{array}{l}0.002 \\
(0.27)\end{array}$ & $\begin{array}{l}0.006 \\
(0.87)\end{array}$ \\
\hline Aged 12_23 months & $\begin{array}{c}-0.965 \\
(12.05)^{* * *}\end{array}$ & $\begin{array}{c}-0.999 \\
(13.15)^{* * *}\end{array}$ & & $\begin{array}{c}-0.997 \\
(12.80)^{* * *}\end{array}$ & $\begin{array}{c}-0.932 \\
(16.78)^{* * *}\end{array}$ \\
\hline Aged 24_35 months & $\begin{array}{l}-1.110 \\
(7.81)^{* * *}\end{array}$ & $\begin{array}{c}-1.099 \\
(7.65)^{* * *}\end{array}$ & & $\begin{array}{l}-1.101 \\
(7.67)^{* * * *}\end{array}$ & $\begin{array}{c}-1.174 \\
(12.50)^{* * *}\end{array}$ \\
\hline Aged 36_47 months & $\begin{array}{l}-1.128 \\
(7.92)^{* * *}\end{array}$ & $\begin{array}{l}-1.114 \\
(7.90)^{* * *}\end{array}$ & & $\begin{array}{l}-1.119 \\
(7.87)^{* * *}\end{array}$ & $\begin{array}{c}-1.189 \\
(12.40)^{* * *}\end{array}$ \\
\hline Aged 48or more months & $\begin{array}{c}-1.069 \\
(8.05)^{* * *}\end{array}$ & $\begin{array}{c}-1.072 \\
(7.81)^{* * *}\end{array}$ & & $\begin{array}{c}-1.076 \\
(7.81)^{* * *}\end{array}$ & $\begin{array}{c}-1.152 \\
(11.88)^{* * *}\end{array}$ \\
\hline Aged 8 years & & & $\begin{array}{c}-0.012 \\
(0.17)\end{array}$ & & \\
\hline Aged 9 years & & & $\begin{array}{l}-0.085 \\
(1.11)\end{array}$ & & \\
\hline $\begin{array}{l}\text { Born in rainy season and aged } \\
\text { less than } 2\end{array}$ & -0.246 & -0.203 & & -0.208 & -0.537 \\
\hline & $(2.56) * *$ & $(2.09)^{* *}$ & & $(2.16)^{* *}$ & $(6.35) * * *$ \\
\hline $\begin{array}{l}\text { Born in rainy season and aged } \\
\text { more than } 2\end{array}$ & -0.049 & -0.041 & & -0.039 & -0.213 \\
\hline & $(0.43)$ & $(0.38)$ & & $(0.36)$ & $(2.53)^{* *}$ \\
\hline Father dead & $\begin{array}{l}-0.095 \\
(1.04)\end{array}$ & $\begin{array}{l}-0.129 \\
(1.45)\end{array}$ & $\begin{array}{c}-0.177 \\
(1.54)\end{array}$ & $\begin{array}{l}-0.123 \\
(1.37)\end{array}$ & $\begin{array}{l}-0.102 \\
(1.26)\end{array}$ \\
\hline Mother dead & $\begin{array}{r}-0.077 \\
(0.54)\end{array}$ & $\begin{array}{r}-0.060 \\
(0.42)\end{array}$ & $\begin{array}{l}-0.142 \\
(1.12)\end{array}$ & $\begin{array}{r}-0.067 \\
(0.47)\end{array}$ & $\begin{array}{l}-0.030 \\
(0.26)\end{array}$ \\
\hline Male & $\begin{array}{l}-0.148 \\
(2.31)^{* *}\end{array}$ & $\begin{array}{l}-0.148 \\
(2.24)^{* *}\end{array}$ & $\begin{array}{c}-0.036 \\
(0.48)\end{array}$ & $\begin{array}{l}-0.153 \\
(2.29)^{* *}\end{array}$ & $\begin{array}{c}-0.203 \\
(3.31)^{* * *}\end{array}$ \\
\hline Father's height & 0.033 & 0.032 & 0.009 & 0.031 & 0.032 \\
\hline
\end{tabular}


Mother's height

Father's height missing

Mother's height missing

Mother's years of education

Father's years of education

Constant

Observations

R-squared

Notes: See table 4

$\begin{array}{ccccc}(4.48)^{* * *} & (4.50)^{* * *} & (1.24) & (4.45)^{* * *} & (5.32)^{* * *} \\ 0.021 & 0.022 & 0.022 & 0.022 & 0.024 \\ (2.87)^{* * *} & (3.03)^{* * *} & (3.11)^{* * *} & (2.90)^{* * *} & (4.25)^{* * *} \\ -0.002 & -0.037 & 0.095 & -0.040 & -0.093 \\ (0.03) & (0.46) & (0.83) & (0.49) & (1.27) \\ 0.048 & 0.077 & -0.055 & 0.074 & 0.128 \\ (0.40) & (0.63) & (0.58) & (0.60) & (1.30) \\ 0.023 & 0.021 & 0.002 & 0.022 & 0.017 \\ (1.88)^{*} & (1.97)^{*} & (0.12) & (2.07)^{* *} & (1.35) \\ 0.016 & 0.010 & 0.019 & 0.012 & 0.018 \\ (1.08) & (0.73) & (1.29) & (0.86) & (1.51)\end{array}$

$\begin{array}{lllll}3006 & 2922 & 1362 & 2922 & 2922\end{array}$ $\begin{array}{llll}0.17 & 0.18 & 0.08 & 0.18\end{array}$

.32)***

.25)***

093

128

$(1.30)$

$(1.35)$

1.51)

total number of different individuals 
Table 6. Reduction (in \%) of the fraction of children stunted and underweight

\begin{tabular}{|c|c|c|c|c|c|c|c|c|c|}
\hline \multirow{2}{*}{$\begin{array}{l}\text { Per capita } \\
\text { income } \\
\text { growth } \\
\text { (in \%) - } \\
\text { since } \\
1993\end{array}$} & \multirow{2}{*}{$\begin{array}{c}\text { Reduction in } \\
\text { income } \\
\text { poverty }(\%)\end{array}$} & \multicolumn{8}{|c|}{ Reduction in malnutrition (\%) } \\
\hline & & $\begin{array}{l}\text { No additiona } \\
\text { interventions }\end{array}$ & $\begin{array}{l}\text { Interventions } \\
\text { in additional } \\
10 \% \text { of } \\
\text { communities }\end{array}$ & $\begin{array}{c}\text { Intervent } \\
\text { ions in } \\
\text { additional } \\
50 \% \text { of } \\
\text { communities }\end{array}$ & $\begin{array}{c}\text { Intervent } \\
\text { ions in all } \\
\text { communities }\end{array}$ & $\begin{array}{c}\text { Farm income } \\
\text { maximum of } \\
75 \% \text { of the } \\
\text { total } \\
\text { household } \\
\text { income }\end{array}$ & $\begin{array}{l}\text { Motor } \\
\text { road in } \\
\text { every } \\
\text { village }\end{array}$ & $\begin{array}{l}\text { Additional } \\
\text { year of } \\
\text { education } \\
\text { to the } \\
\text { father }\end{array}$ & $\begin{array}{c}\text { Ratio of } \\
\text { children } \\
\text { vaccinated } \\
\text { increased } \\
\text { to } 95 \%\end{array}$ \\
\hline \multicolumn{10}{|c|}{ Height for age } \\
\hline 0 & 0 & 0.0 & 7.0 & 41.3 & 68.7 & 3.3 & 6.2 & 8.1 & 9.6 \\
\hline 0.5 & 24.7 & 2.6 & 9.1 & 42.7 & 69.2 & 6.0 & 8.9 & 10.2 & 11.2 \\
\hline 1 & 44.1 & 5.3 & 11.5 & 44.4 & 70.3 & 7.8 & 11.5 & 12.4 & 13.3 \\
\hline 1.5 & 55.7 & 7.1 & 14.2 & 46.3 & 71.9 & 9.6 & 13.1 & 14.9 & 14.7 \\
\hline 2 & 66.6 & 8.7 & 16.3 & 48.1 & 73.2 & 11.6 & 14.6 & 16.4 & 17.2 \\
\hline 2.5 & 79.0 & 11.8 & 17.7 & 49.5 & 74.0 & 13.9 & 17.7 & 18.5 & 18.6 \\
\hline 3 & 84.1 & 13.9 & 19.2 & 51.0 & 75.2 & 16.6 & 19.9 & 20.5 & 20.5 \\
\hline \multicolumn{10}{|c|}{ Underweight } \\
\hline 0 & 0 & 0 & 11.0 & 31.7 & 53.4 & 1.8 & 2.4 & 3.6 & 9.9 \\
\hline 0.5 & 24.7 & 3.4 & 14.1 & 34.4 & 55.5 & 5.2 & 5.8 & 7.0 & 12.9 \\
\hline 1 & 44.1 & 6.8 & 17.2 & 37.0 & 57.6 & 8.5 & 9.1 & 10.3 & 15.9 \\
\hline 1.5 & 55.7 & 10.1 & 20.2 & 39.5 & 59.6 & 11.8 & 12.4 & 13.5 & 18.8 \\
\hline 2 & 66.6 & 13.3 & 23.2 & 42.0 & 61.5 & 15.0 & 15.6 & 16.7 & 21.7 \\
\hline 2.5 & 79.0 & 16.5 & 26.0 & 44.4 & 63.4 & 18.1 & 18.7 & 19.7 & 24.5 \\
\hline 3.0 & 84.1 & 19.5 & 28.8 & 46.7 & 65.1 & 21.1 & 21.7 & 22.7 & 27.2 \\
\hline
\end{tabular}

Note: Simulations are based on the random effect regression model, which is our preferred estimation strategy.

The simulations were done taking 1993 as the base year. Since the per capita income growth rate between 1993-2003 is known (0.7\% per annum - URT 2004), the effective growth rates required to attain the 1993-2015 mean growth rates $0 \%, 1 \%, 2 \%$ and $3 \%$ for the $2003-2015$ period are respectively: $-0.5 \%, 1.3 \%, 3.1 \%$, and $5.0 \%$. Figures in bold show the attainment of the MDG. 


\section{Appendix 1.}

Table A1. Determinants of feeding posts placement. Dependent variable: presence of Partage / feeding post in the village

\begin{tabular}{|c|c|}
\hline Explanatory variables & coefficient \\
\hline Mean of (log) per capita consumption in the village & $\begin{array}{l}0.101 \\
(1.48)\end{array}$ \\
\hline Daily Market in Community & $\begin{array}{c}0.121 \\
(2.61)^{* * *}\end{array}$ \\
\hline Crop disaster in past 10 years & $\begin{array}{c}0.273 \\
(2.76)^{* * *}\end{array}$ \\
\hline Drought disaster in past 10 years & $\begin{array}{c}-0.054 \\
(1.11)\end{array}$ \\
\hline AIDS main adults' death cause & $\begin{array}{l}0.045 \\
(0.97)\end{array}$ \\
\hline Mean male height of adults aged 25-32 & $\begin{array}{l}-0.003 \\
(0.60)\end{array}$ \\
\hline Mean female height of adults aged 25-32 & $\begin{array}{l}0.002 \\
(0.31)\end{array}$ \\
\hline Urban & $\begin{array}{l}-0.017 \\
(0.27)\end{array}$ \\
\hline Health worker in village & $\begin{array}{c}-0.120 \\
(2.08) * *\end{array}$ \\
\hline Distance to the closest health center & $\begin{array}{l}-0.013 \\
(1.96)^{*}\end{array}$ \\
\hline Is Motorable Road Near & $\begin{array}{l}-0.041 \\
(0.35)\end{array}$ \\
\hline Road impassable & $\begin{array}{c}0.115 \\
(2.46)^{* *}\end{array}$ \\
\hline Ratio of children aged $0-3$ that are vaccinated & $\begin{array}{l}-0.198 \\
(1.75)^{*}\end{array}$ \\
\hline Constant & $\begin{array}{c}-0.612 \\
(0.37)\end{array}$ \\
\hline $\begin{array}{l}\text { Observations } \\
\text { R-squared }\end{array}$ & $\begin{array}{l}197 \\
0.21\end{array}$ \\
\hline
\end{tabular}

Note: Regression based on observations at village level and not on the entire sample of children's

observations. Absolute value of t statistics in parentheses. $*$ indicates significance at $10 \%$ level; $* *$ at $5 \%$ and *** significant at $1 \%$ level of confidence. 